\title{
Impact of pH Modification on Protein Polymerization and Structure-Function Relationships in Potato Protein and Wheat Gluten Composites
}

\author{
Faraz Muneer ${ }^{1}{ }^{\mathbb{D}}$, Eva Johansson ${ }^{1}{ }^{\mathbb{D}}$, Mikael S. Hedenqvist $^{2}$, Tomás S. Plivelic ${ }^{3}$ and \\ Ramune Kuktaite ${ }^{1, *(D)}$ \\ 1 Department of Plant Breeding, Swedish University of Agricultural Sciences, Box 101, SE-23053 Alnarp, \\ Sweden; faraz.muneer@slu.se (F.M.); eva.johansson@slu.se (E.J.) \\ 2 KTH Royal Institute of Technology, School of Engineering Sciences in Chemistry, Biotechnology and Health, \\ Fibre and Polymer Technology, SE-10044 Stockholm, Sweden; mikaelhe@kth.se \\ 3 MAX-IV Laboratory, Lund University, Box 118, SE-22100 Lund, Sweden; tomas.plivelic@maxiv.lu.se \\ * Correspondence: ramune.kuktaite@slu.se; Tel.: +46-40-41-5337
}

Received: 12 November 2018; Accepted: 20 December 2018; Published: 24 December 2018

\begin{abstract}
Wheat gluten (WG) and potato protein (PP) were modified to a basic $\mathrm{pH}$ by $\mathrm{NaOH}$ to impact macromolecular and structural properties. Films were processed by compression molding (at 130 and $150{ }^{\circ} \mathrm{C}$ ) of WG, PP, their chemically modified versions (MWG, MPP) and of their blends in different ratios to study the impact of chemical modification on structure, processing and tensile properties. The modification changed the molecular and secondary structure of both protein powders, through unfolding and re-polymerization, resulting in less cross-linked proteins. The $\beta$-sheet formation due to $\mathrm{NaOH}$ modification increased for WG and decreased for PP. Processing resulted in cross-linking of the proteins, shown by a decrease in extractability; to a higher degree for WG than for PP, despite higher $\beta$-sheet content in PP. Compression molding of MPP resulted in an increase in protein cross-linking and improved maximum stress and extensibility as compared to PP at $130^{\circ} \mathrm{C}$. The highest degree of cross-linking with improved maximum stress and extensibility was found for WG/MPP blends compared to WG/PP and MWG/MPP at $130^{\circ} \mathrm{C}$. To conclude, chemical modification of PP changed the protein structures produced under harsh industrial conditions and made the protein more reactive and attractive for use in bio-based materials processing, no such positive gains were seen for WG.
\end{abstract}

Keywords: wheat gluten; potato protein; chemical pre-treatment; structural profile; tensile properties

\section{Introduction}

Wheat gluten (WG) and potato protein (PP) are industrial side-streams originating from wheat and potato processing into ethanol and potato starch, respectively. Both protein-rich by-products are currently mostly utilized in baking (e.g., WG) and animal feed industries (PP). In addition, both of these proteins have attractive properties as raw materials for non-food applications such as in bio-based plastics [1,2]. During the production processes of WG and PP, high drying temperature is utilized, and for PP, an acid mediated coagulation step is also included. Both procedures are known to denature the chemical and structure-determining bonds in the protein and may also result in ionization of amino, carboxyl and phenolic groups [3] and reduced protein functionality [2,4,5]. In addition, for PP being treated at a low $\mathrm{pH} \approx 4$ during industrial processing, causing definite changes in chemical and physical properties to occur. The chemical processes resulting in intra- and intermolecular changes of the protein limit their processing window, thereby decreasing their suitability for processing into bio-based materials [2,6]. Similarly for WG, the relatively high temperature during drying negatively 
impacts the proteins and results in aggregated gluten with limited functionality [5]. An alternative and added-value opportunity is to use chemical tools to retain the WG and PP processing ability, both in their present or modified form, for benefit of industry, the consumer and society, thereby contributing to the circular bio-economy. Manipulating the chemical nature of industrial WG and PP would create new possibilities and contribute to the development of alternative uses and an added-value of these proteins for different applications. Development of new bio-based materials from WG and PP proteins is one such promising application.

Un-plasticized WG and PP are difficult to process as their glass transition temperature $\left(T_{\mathrm{g}}\right)$ is located close to their thermal degradation temperature [2,7-9]. Thus, easy processing requires the addition of chemical agents or polyol-based plasticizers that depress $T_{\mathrm{g}}$ and widen the processing window $[2,4,10,11]$. In general, proteins perform better in terms of their structure-functional properties when they are processed at basic $\mathrm{pH}[12,13]$. The basic $\mathrm{pH}$ is known to denature and unfold the proteins and thereby expose sulfhydryl and hydrophobic protein sections, which open-up for new protein interactions when processed [14].

Chemical additives, such as $\mathrm{NaOH}, \mathrm{NH}_{4} \mathrm{OH}$ or urea, create basic conditions for the protein, resulting in changes of secondary and supramolecular protein structures which correlate with improved functional properties of processed materials $[7,9,10,12,13,15-17]$. However, previous studies have mainly focused on additives or chemical modifiers being added directly to the protein where the blend was immediately processed, thereby leaving a short reaction time for additives to interact with the protein. Although, pre-treatment of the proteins with chemical modifiers in order to modify the protein and later use it for processing has not been evaluated before. This has left a gap for further investigations on the impact of such chemical pre-treatment on protein structure and also functional properties of the final product. In this study, we pre-treated the WG and PP with $\mathrm{NaOH}$ in a solution to achieve a basic $\mathrm{pH}$ and to promote protein unfolding and induce reactivity. The $\mathrm{pH}$ modification was aimed to promote new protein-protein interactions, that could positively impact the mechanical performance of the protein films and composites. The objective was also to understand the effect of the chemical modification on protein molecular and secondary structures, processing behavior and mechanical performance of composites with varying WG and PP ratios. Increased understanding of protein-protein interactions and chemistry, as well as structure-function relationships of proteins in a blend can offer novel opportunities to create versatile and attractive performance of films and composites.

\section{Results and Discussion}

\subsection{Protein Extractability in $\mathrm{pH}-$ Modified Protein Powders, Films and Composites}

In this study, SE-HPLC was used to assess protein polymerization behavior in the $\mathrm{pH}$ modified protein powders and high temperature processed films (Figure 1). The modified potato protein (MPP) and modified wheat gluten (MWG) powders showed greater amounts of extractable polymeric proteins (HMw and LMw) compared to the non-modified samples, PP and WG (Figure 1a-d). This was particularly evident for the HMw proteins extracted during 2Ex and 3Ex extractions (Figure 1b,d). The results indicated, that the alkaline $\mathrm{pH}$ induced unfolding in the studied protein and made the proteins more extractable.

For protein films and composites processed at two temperatures, 130 and $150{ }^{\circ} \mathrm{C}$, variation in protein extractability was observed. The processing of the protein powders into films at high temperature induced a higher degree of protein cross-linking and promoted the formation of larger protein aggregates and polymers, thereby decreasing their extractability during SE-HPLC analysis as has previously been reported in processed protein based materials $[2,4,12,16,18-20]$. In addition, possible interactions of the proteins studied with residual starches (wheat starch from wheat gluten fraction and potato starch from potato protein fraction) could have potentially occurred through non-covalent reactions such as, hydrogen and van der Waals-bonding between the protein and reactive 
hydroxyl groups from starch. Although those interactions were minor and did not substantially impact protein cross-linking.

For the pressed materials in this study an increase in protein extractability was seen for protein materials pressed at $150{ }^{\circ} \mathrm{C}$, as compared to those pressed at $130{ }^{\circ} \mathrm{C}$ (Figure 1e). This increase in extractability in films pressed at the higher temperature $\left(150^{\circ} \mathrm{C}\right)$, was mainly due to an increase in LMw proteins being extracted as a consequence of protein degradation (except, for MWG, in which increase in $\mathrm{HMw}$ proteins at higher temperature was also observed) and lack of protein-protein interactions. In addition, proteins from films produced from the chemically modified proteins were in general more easily extractable, with the exception of MPP pressed at $130{ }^{\circ} \mathrm{C}$ (compare MPP with PP pressed at $130^{\circ} \mathrm{C}$; Figure 1e).
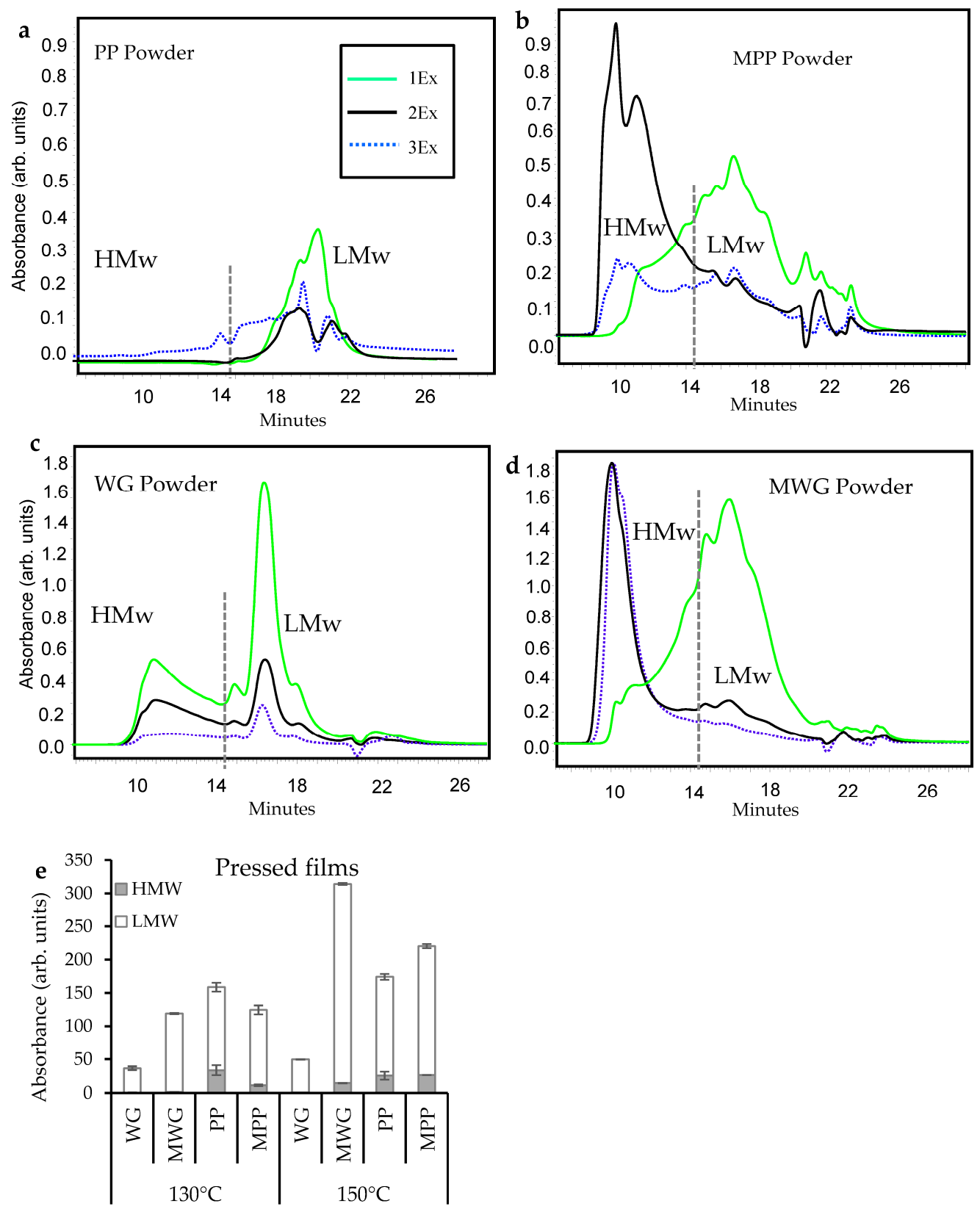

Figure 1. Representative chromatograms of protein molecular size distribution of potato protein powder (PP) (a), modified potato protein powder (MPP) (b), wheat gluten (WG) (c) and modified wheat gluten (MWG) powder (d), and the total protein extractability of films from the 3 extractions of non-modified and $\mathrm{pH}$-modified proteins pressed at $130{ }^{\circ} \mathrm{C}$ and $150{ }^{\circ} \mathrm{C}(\mathbf{e})$. 
The protein extractability results clearly suggests that the basic $\mathrm{pH}$-modification of protein powders contributed to a protein network unfolding, decrease in protein-protein interactions and de-polymerization of protein aggregates being present in the non-modified protein powder. The unfolding, decrease of protein-protein interactions and de-polymerization of the proteins after modification resulted in an increased extractability of the proteins. The fact that the extractability increased primarily as HMw proteins were extracted during 2Ex and 3Ex extraction steps (where sonication energy is used), suggests that primarily protein aggregates/polymers were affected by the $\mathrm{pH}$ adjustment (chemical modification). However, the majority of the protein extraction taking place at 2Ex and 3Ex indicated the presence of some of the cross-links, although with lower degree of intermolecular disulphide bonds, while hydrogen bonds and non-covalent protein interactions might still be in place $[21,22]$.

Compression molding of the powder into films resulted in excessive cross-linking and re-formation of intermolecular disulphide bonds for all samples, as this has been previously reported for wheat gluten and potato protein materials $[2,11,16,19,23]$. In particular, most of the HMw proteins in all the hot pressed samples ended up in forming large polymers, which were not extractable in the films after pressing. It is also known from previous studies that compression molding of films under alkaline conditions leads to increased protein-protein interactions with the formation of disulphide cross-links in WG, hydrogen bonding in WG and PP and also the formation of isopeptide bonds such as dehydroalanin, lanthionine and lysinoalanine [7,16,24-26]. In addition, alkaline $\mathrm{pH}$ and the use of cross-linking enzymes, such as transglutaminase, for protein pre-treatment can further introduce new protein cross-linking opportunities, as has been shown in grass pea flour films [27]. Also, newly sourced transglutaminase species that have been shown to positively impact certain functional behavior of proteins in wheat dough $[28,29]$ should further be explored in protein-based materials.

In this study, the proteins were found to be less polymerized after hot pressing at $150{ }^{\circ} \mathrm{C}$ than at $130{ }^{\circ} \mathrm{C}$, most likely due to protein degradation, with HMw proteins breaking into LMw fragments $[8,23]$. In terms of nano-structure for unmodified WG and PP samples pressed at 130 and $150{ }^{\circ} \mathrm{C}$, few differences due to high temperature were observed in the main scattering broad peak, $d_{1}$ and for the scattering distance $d_{2}$, studied by SAXS, for both types of proteins (supporting information, Figure S1). For the PP film, the broad peak $\left(d_{1}\right)$ became "sharper", while $d_{2}$ intensity decreased with increasing temperature. While for the WG film, at $150{ }^{\circ} \mathrm{C}$ the scattering distance, $d_{2}$, disappeared, indicated a less complex structural morphology compared to the previously observed structural morphologies in WG films pressed at $130{ }^{\circ} \mathrm{C}$ [5]. A possible explanation is a decrease in polymerization and an increase in protein breakdown as shown by SE-HPLC (Figure 1e). Regarding the PP film morphology, intensity of the $d_{2}$ peak was higher at $130{ }^{\circ} \mathrm{C}$ than at $150{ }^{\circ} \mathrm{C}$, indicating more structural complexity, although without any specific peak ratio [2]. This change in peak position and intensity may be affected by protein polymerization behavior, which was observed at different pressing temperatures. Regarding the MWG and MPP films morphology, the MPP showed a clear peak, $d_{1}$, indicating similar structural morphology observed previously for the PP films pressed at $130{ }^{\circ} \mathrm{C}$ [2] (supporting information, Figure S2). While MWG showed $d_{1}$ and $d_{2}$, scattering distances, that can be referred to some undefined, though poorly hierarchically arranged structural entities (as compared to previously observed hexagonal arrangement of WG proteins). Thus, modification may not have considerably changed the nano-structure of MPP, while MWG nanostructure was not improved.

Previous study of WG has indicated that a less polymerized structure in the powder used for processing contributes to a higher degree of re-polymerization, chemical flexibility for proteins to interact and cross-link during processing, and the availability of chemically reactive sites for disulphide bond formation [5]. Although, the described effect could not be seen for the WG proteins in this study, indicating the alkali modification either leads to irreversible changes in the protein conformation (negative impact) or to chemical reactions not involving disulphide bond formation. 


\subsection{Protein Extractability in Pressed Composites}

Among the pressed composites the highest protein extractability was clearly seen for the MWG/MPP samples at $150^{\circ} \mathrm{C}$, almost independent of the ratio of the two modified proteins within the composite (Figure 2). These results corresponded well with the high protein extractability found for the modified proteins pressed individually at $150{ }^{\circ} \mathrm{C}$ (compare Figure 1e), although protein extractability was even higher in the composites than in the pressed films of individual proteins. Thus, mixing of the two modified proteins did not contribute to increased protein polymerization as compared to protein polymerization for the modified proteins separately. Similarly, a high proportion of MWG (50 and 70\%) in the composites pressed at $130^{\circ} \mathrm{C}$ resulted in increased protein extractability as compared to the films from each of the individually modified proteins (Figure 2a compared with Figure 1). The extractability was also increased with the increase in temperature from 130 to $150{ }^{\circ} \mathrm{C}$ and with higher MWG content in the blend (Figure 2). An increased protein extractability with increase in MWG content (at $130{ }^{\circ} \mathrm{C}$ ) could be due to the fact that MWG has a more complex protein molecular structure and chemistry, compared to PP, and was more denatured and depolymerized in the $\mathrm{pH}$-modification process compared to PP (see MWG and MPP powder profiles; Figure 1b,d). Therefore, an MWG increase in the MWG/MPP blends (i.e., the 70/30 sample) resulted in a decrease in polymerization and lack of disulphide cross-link formation compared to 30/70 and 50/50 samples. However, using a $150{ }^{\circ} \mathrm{C}$ pressing temperature reduced the protein polymerization (increased protein extractability) for all MWG/MPP compositions compared to the individual modified proteins (compare Figures 1 and $2 b$ ). This increase in protein extractability at higher temperature may be due to the lack of disulphide and irreversible cross-links between the protein chains and also due to breakdown of HMw protein into LMw fragments.
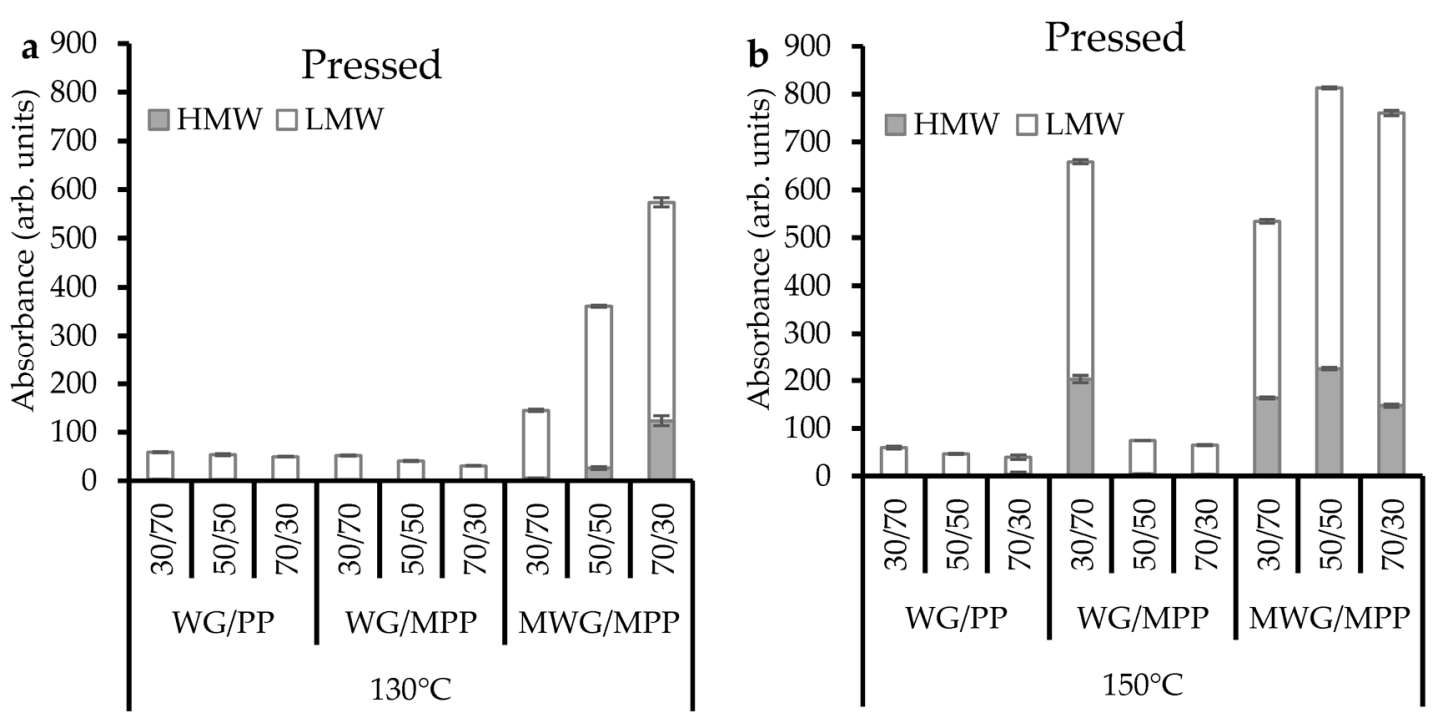

Figure 2. Total protein extractability of WG/PP, WG/MPP and MWG/MPP samples pressed at $130{ }^{\circ} \mathrm{C}$ (a) and $150{ }^{\circ} \mathrm{C}(\mathbf{b})$, as studied by SE-HPLC.

For the composites based on non-modified proteins (WG/PP), such an increase in protein extractability (as seen for modified samples) was not seen (compare Figures 1 and 2); instead a slight decrease in protein extractability was observed, especially at high WG ratios (70/30). The non-modified (as received) WG and PP have a low extractability due to the formation of HMw protein aggregates during their industrial processing [2,5]. Therefore, their further processing at high temperatures favored the formation of non-reducible protein cross-links and also incorporation of the LMw fragments in larger protein networks, thus reducing their extractability $[8,22,30]$. This suggests that composites of non-modified proteins produced in this study did show reduced protein extractability as reported for individual protein based materials produced previously $[2,19]$. 
As for the WG (non-modified) composites with different ratios of MPP, the protein extractability was in a similar range to that of WG/PP films at both pressing temperatures (compare Figures 1 and 2) except for WG/MPP $30 / 70$ at $150{ }^{\circ} \mathrm{C}$ with surprisingly higher amounts of extractable proteins. Hence, higher pressing temperature (as $150^{\circ} \mathrm{C}$ ) increased protein polymerization and decreased extractability when $\leq 50 w t . \%$ of MPP was used. No such effect of temperature and amount used of MPP was seen in the samples pressed at $130{ }^{\circ} \mathrm{C}$, suggesting that high temperature may be one of the main driving factors in determining the protein polymerization.

Interestingly, the lowest protein extractability (highest degree of protein polymerization) was found for the $70 / 30 \mathrm{WG} / \mathrm{MPP}$ composite film at $130{ }^{\circ} \mathrm{C}$, and for the $70 / 30 \mathrm{WG} / \mathrm{PP}$ film at $150{ }^{\circ} \mathrm{C}$ (Figure 2). Thus, to increase protein polymerization in WG based films, modified potato protein (MPP) is beneficial at $130{ }^{\circ} \mathrm{C}$, while non-modified PP is beneficial to have at higher temperature. Increased protein polymerization in 70/30 WG/MPP could be explained by a higher degree of protein cross-linking of $\mathrm{WG}$ at $130^{\circ} \mathrm{C}$ as has been reported in previous studies $[5,19,31]$. However, an increased protein polymerization in WG/PP 70/30 sample at $150{ }^{\circ} \mathrm{C}$ suggests formation of new protein-protein interactions in a composite, because the extractability of these blends decreased slightly more when compared to both non-modified proteins pressed at $150{ }^{\circ} \mathrm{C}$.

\subsection{Effect of Chemical Modification on Secondary Structure of Proteins}

As shown in previous studies [5,10,12,31-33], the non-modified WG powder showed relatively low amounts of $\beta$-sheets, as indicated by a flat shoulder in the amide I region $\left(1620-1625 \mathrm{~cm}^{-1}\right)$, while peaks at 1660,1650 and $1641 \mathrm{~cm}^{-1}$ verified the presence of $\alpha$-helices, $\alpha$-helices and random coils, and unordered structures, respectively (Figure 3a). Chemical modification of the WG protein (MWG sample) resulted in a slight decrease in the intensity of peaks in the region $1640-1660 \mathrm{~cm}^{-1}$, indicating that some of either $\alpha$-helices, $\alpha$-helices and random coils, or unordered structures became involved in formation of strong hydrogen bonded $\beta$-sheets (Figure 3a). Thus, FT-IR data indicate formation of $\beta$-sheets at the expense of either $\alpha$-helices, $\alpha$-helices and random coils or unordered structures, may indicate development of novel interactions (presumably via hydrogen bonds, protein-protein and peptide-protein interactions [34]), although not verified by SE-HPLC results (Figure 1).

The FT-IR spectra of PP showed a very distinct and high intensity peak at $1622 \mathrm{~cm}^{-1}$ verifying the presence of strongly hydrogen-bonded $\beta$-sheets. The formation of these protein structures are known to originate from the harsh treatment of the PP during industrial extraction with the use of high temperature and acidic processing conditions promoting a high degree of cross-linking [2]. The high degree of cross-linking in PP was also supported by the SE-HPLC data, showing low extractability of PP powder (Figure 1a). Furthermore, results of the SE-HPLC were supported by FT-IR data for the MPP powder sample, in general showing a lower amount of strongly hydrogen-bonded $\beta$-sheets (less aggregated structure) as reported in previous studies $[4,34,35]$.

The pressed WG/PP blended films resulted in FT-IR spectra with a clear and high intensity peak at $1620 \mathrm{~cm}^{-1}$ and also several well defined peaks in the $1640-1660$ and $1622 \mathrm{~cm}^{-1}$ region (Figure $3 \mathrm{~b}, \mathrm{c}$ ), thereby showing structural features resembling both single powders used in the blend (Figure 3a) and indicating presence of strongly bonded $\beta$-sheet interactions, $\alpha$-helices, $\alpha$-helices and random coils, and unordered structures [2,5]. Including MPP in the blends (WG/MPP) for compression molding resulted in FT-IR spectra with reduced intensity and a shift to lower frequency of the major $\beta$-sheet peak (especially at $150{ }^{\circ} \mathrm{C}$ when the shoulder also became broader), and a decrease in intensity of the peaks in the region of $1640-1660 \mathrm{~cm}^{-1}$ (Figure 3b,c). In general protein aggregation has been correlated to an increased amount of strongly hydrogen-bonded $\beta$-sheets contributing to ordered conformation and improved tensile strength $[2,4,7,10,12,31-34,36-38]$. However, the lowest extractability of the proteins (indicating protein polymerization) as resolved by SE-HPLC results (Figure 2) was found for WG/MPP $70 / 30$ at $130{ }^{\circ} \mathrm{C}$ and WG/PP $70 / 30$ at $150{ }^{\circ} \mathrm{C}$, not corresponding with blends showing the most intense peak for $\beta$-sheets by FT-IR (Figure $3 b, c)$. These results suggest that the protein polymerization behavior and relationships with structural properties seems to be more complicated for compression molded 
composites than for individual proteins, especially while modifying of the chemical structures of the proteins used in the blends.

FT-IR spectra of MWG/MPP composites showed more differentiation between the ratios of proteins, where the strongly hydrogen-bonded $\beta$-sheets related structural peak was more pronounced at higher PP ratio and lower temperature (supporting information, Figure S3), corresponding to lower protein extractability by SE-HPLC (Figure 2). This might indicate that differences in protein polymerization were too limited among WG/PP and WG/MPP blended compression molded films to be differentiated by FT-IR in most cases, and basically only differences between separate blended protein components were seen. Thus, only for differences in protein polymerization behavior of MWG/MPP blends were large enough to be differentiated by FT-IR as also indicated by SE-HPLC, and corresponded to the characteristic relationship of SE-HPLC, FT-IR and functional properties data $[12,31]$.
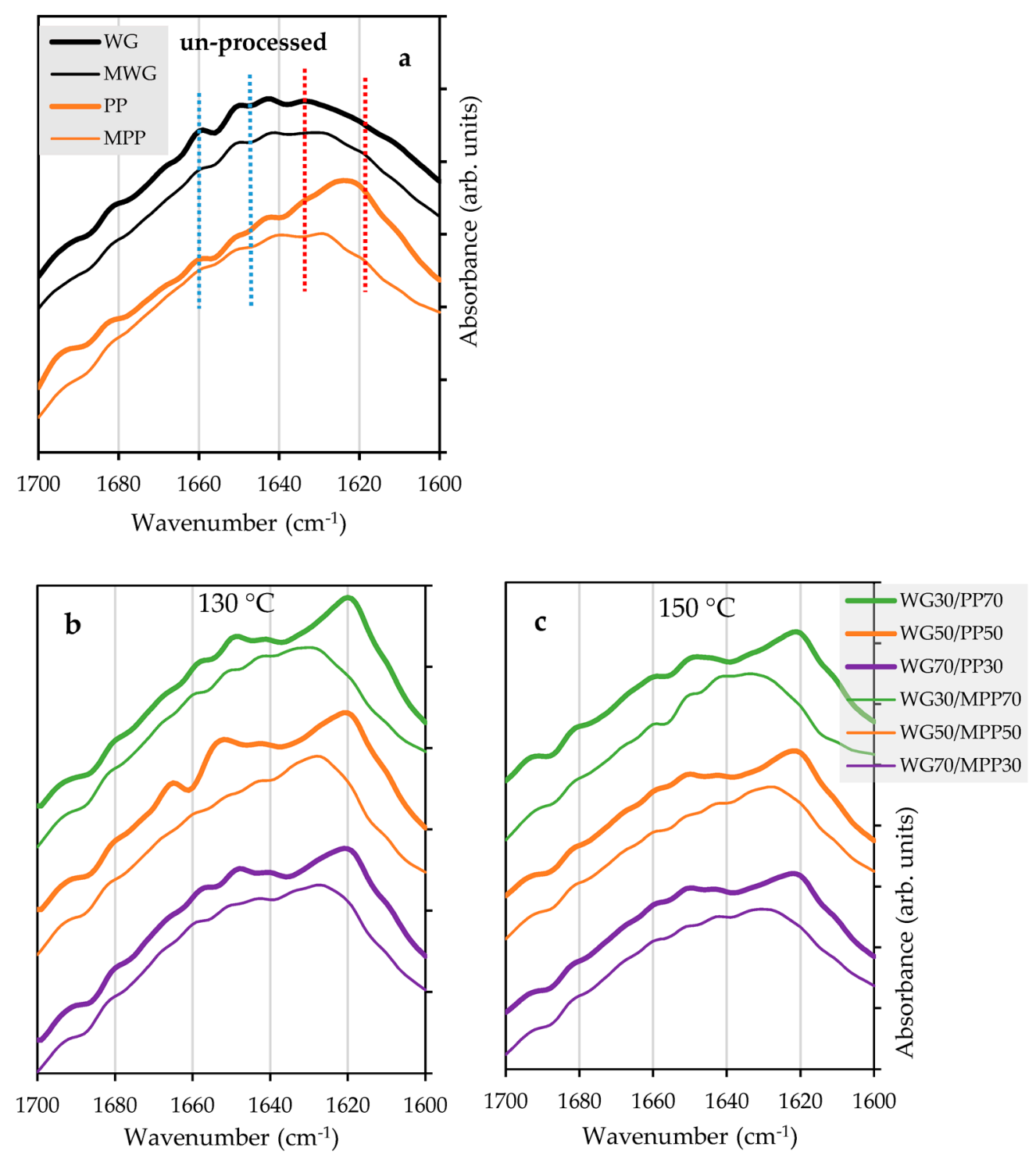

Figure 3. FT-IR spectra of individual protein powders and pressed films at 130 and $150{ }^{\circ} \mathrm{C}$. WG, MWG, PP and MPP powders (a), pressed samples of WG/MPP blends along with controls $(\mathbf{b}, \mathbf{c})$.

\subsection{Effect of Protein Modification on Mechanical Performance of the Pressed Composites}

Compression molding of WG, MWG, PP, MPP and their blends, yielded samples of different colors as can be seen in Figure 4. High WG and MWG content generally resulted in a sample with 
light brown color (Figure 4, MWG100 and WG/MPP 70/30), while high PP and MPP content generally resulted in samples with dark brown (WG/PP 30/70) or almost black in color (MPP100), which can influence the composites' attractiveness and end-use. It is however an easy task to incorporate a pigment or dye to obtain a desired color (excluding white color). WG and PP samples showed opposite tensile performance, WG having lower strength and E-modulus but higher extensibility (elongation at break) than PP. Thus, comparing these two protein types, the tensile strength correlated positively with protein extractability. This observation was different to many previous studies, where a higher degree of cross-linking yielded higher strengths $[2,5,19,22,39,40]$. Here, the WG proteins most likely have a higher ability to cross-link (due to their more complex molecular structure characteristics and specific polymerization properties $[8,22]$ ) during pressing than the PP as SE-HPLC results indicate, although FT-IR shows a higher degree of $\beta$-sheets in the pressed PP which might explain their higher maximum stress and E-modulus [2].
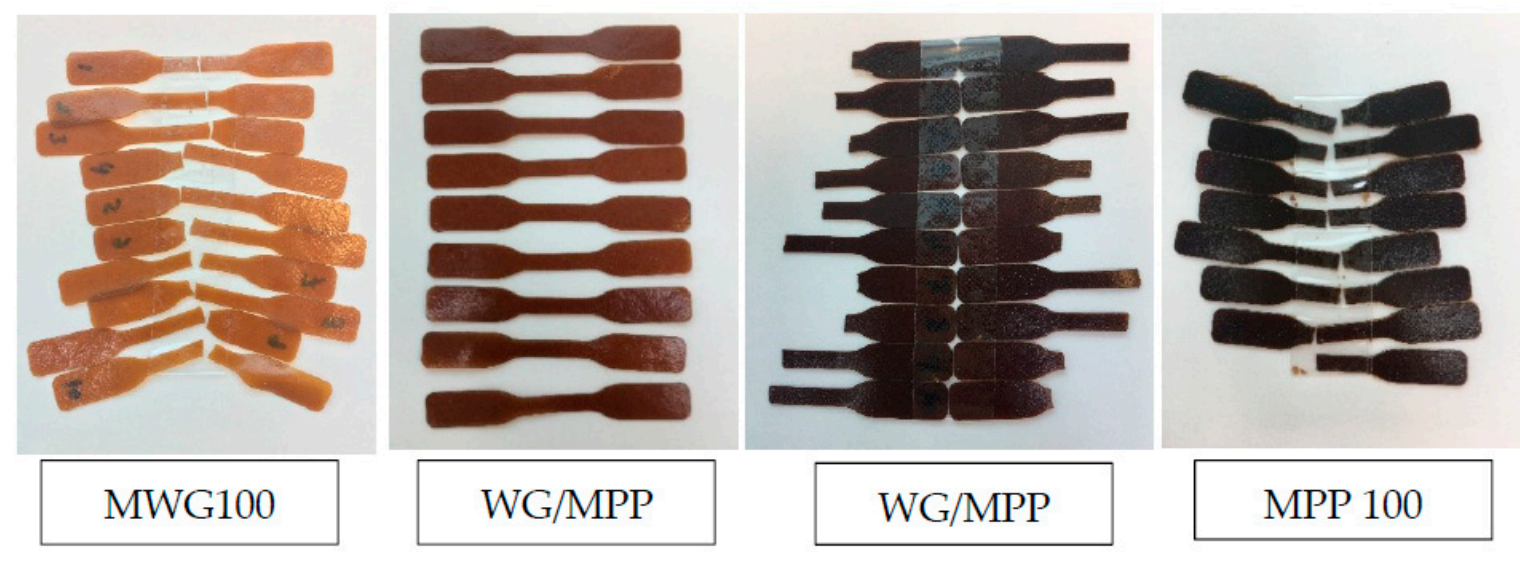

Figure 4. Representation of the range of colors of films and composites MWG100, WG/MPP 70/30, WG/MPP 30/70 and MPP100 pressed at $130{ }^{\circ} \mathrm{C}$.

Modification of WG (MWG) resulted in lower maximum stress and E-modulus and reduced extensibility compared to WG for both evaluated pressing temperatures (Figure 5). Modification of the PP (MPP), resulted in a decrease in E-modulus for samples pressed at both temperatures and maximum stress decreased at $150{ }^{\circ} \mathrm{C}$ while the extensibility increased particularly at $130^{\circ} \mathrm{C}$ (Figure 5). SE-HPLC data indicated an increase in cross-linking at $130{ }^{\circ} \mathrm{C}$, although a decrease in $\beta$-sheet content was shown by FT-IR, which might explain the improvement in the extensibility and decrease in E-modulus for the MPP as compared to PP. In addition, a previous study reported an increase in extensibility and a decrease in modulus for PP modified with $\mathrm{NaOH}$, when pressed with $30 \%$ glycerol [4]. Thus, modification of PP prior to processing (e.g., hot pressing) leads to improved tensile properties but also contributes to opportunities for using lower processing temperatures than was used in previous studies $\left(\geq 150^{\circ} \mathrm{C}\right)[2]$, thereby saving energy input during the production process.

The pressed composites of WG and PP resulted in tensile properties generally as expected from the ratios of the individually pressed proteins (Figure 5). In addition, pressed WG/MPP samples showed tensile properties generally between those of the individually pressed protein samples, although minor differences were seen among the samples. Furthermore, as also indicated by comparing FT-IR and SE-HPLC results, differences in the protein cross-linking obtained by SE-HPLC could not explain the differences in tensile properties between the WG/PP and WG/MPP blends.

The most rubber-like properties were observed for the pressed MWG material (lower stiffness than WG), which also resulted in that the MWG/MPP blends were with the most rubber-like properties (low modulus but still with appreciable extensibility) (Figure 5), thereby correlating with SE-HPLC and FT-IR data. It is noteworthy that the higher pressing temperature $\left(150{ }^{\circ} \mathrm{C}\right)$ leads to lower stiffness, strength and extensibility for the modified materials and their blends (MWG, MPP and MWG/MPP) (Figure 5). 

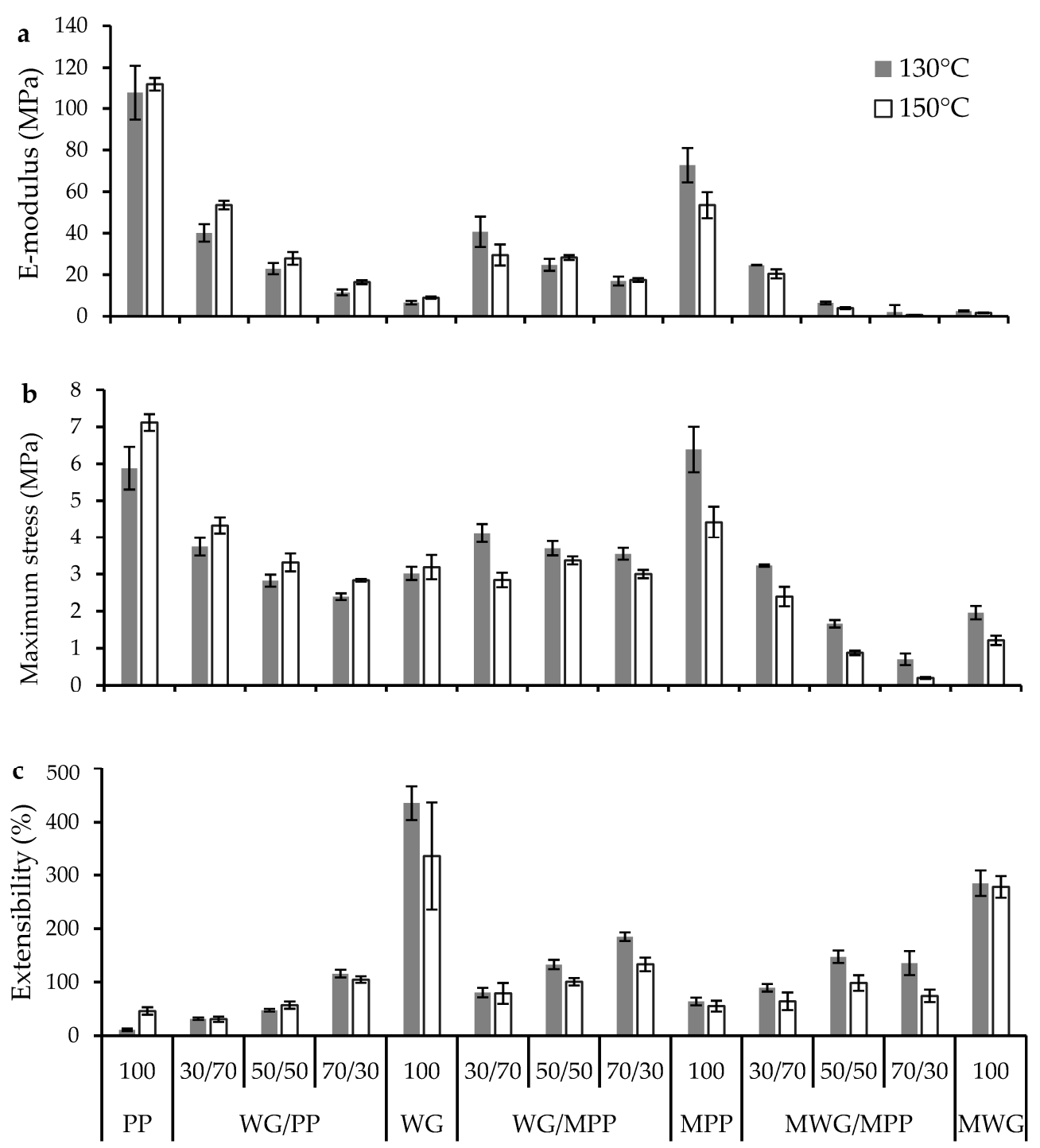

Figure 5. Mechanical properties of individual protein films and WG/PP, WG/MPP and MWG/MPP blends pressed at 130 and $150{ }^{\circ} \mathrm{C}$; (a) E-modulus, (b) maximum stress and (c) extensibility.

\section{Materials and Methods}

\subsection{Wheat Gluten and Potato Proteins}

Wheat gluten with protein content of $77.7 w t . \%$, starch $5.8 w t . \%$, moisture $6.9 w t . \%$ and fat $1.2 w t . \%$, was purchased from Lantmännan Reppe AB, Lidköping, Sweden. Commercial PP was supplied by Lyckeby Starch AB, Kristianstad, Sweden. The potato protein content was 82.2 wt.\% (Dumas method, Flash 2000 NC Analyser, Thermo Scientific, USA, NX 6.25) and moisture content of $8.1 \%$ (dry basis, dried at $105{ }^{\circ} \mathrm{C}$ for $3 \mathrm{~h}$ ). Glycerol (purity $99.5 \mathrm{wt.} \%, 0.5 \mathrm{wt} \%$ water) was supplied by Karlshamns Tefac $\mathrm{AB}$, Karlshamn, Sweden.

\subsection{Protein Modification}

Potato protein powder, $50 \mathrm{~g}$ was slowly dispersed in $600 \mathrm{~mL}$ distilled water under stirring. The suspension was adjusted to $\mathrm{pH} 10$ by addition of a $5 \mathrm{M} \mathrm{NaOH}$ solution, followed by stirring for $30 \mathrm{~min}$ at $75^{\circ} \mathrm{C}\left( \pm 3^{\circ} \mathrm{C}\right)$. The PP was well dispersed in these conditions forming a dark brown suspension. The PP suspension was then lyophilized and ground to powder using an IKA A10 grinder (IKA, Germany) and was designated as modified PP (MPP) in this study. WG was modified in the same way as the PP above and was designated as modified WG (MWG). Protein blends were prepared 
by dispersing various ratios of WG and PP in water followed by the $\mathrm{pH}$ modification step as described for the separate protein sources. Thereafter, MWG/MPP blend were lyophilized and ground to obtain powder for further sample processing.

\subsection{Sample Preparation and Compression Molding}

Powders from individually modified PP and WG proteins were mixed with glycerol, (70 wt.\% protein and $30 w t . \%$ glycerol) prior to compression molding and later pressed into films. Each type of protein was pressed into two films, one at $130{ }^{\circ} \mathrm{C}$ and another one at $150{ }^{\circ} \mathrm{C}$. For blends, different ratios of WG/PP and WG/MPP (30/70, 50/50 and 70/30) were manually mixed with glycerol, (70 wt.\% protein and $30 w t . \%$ glycerol) prior to compression molding. The sample compositions are presented in Table 1 . The prepared individual protein films and blends were then placed in a $0.5 \mathrm{~mm}$ thick aluminum frame with a $100 \times 100 \mathrm{~mm}$ opening to control the size and thickness of the film. The film and blends were then molded for $5 \mathrm{~min}$ at 200 bar in a hydraulic press (Polystat 400s, Servitech, Germany) between pre-heated aluminum plates with poly(ethylene terephthalate) release films. From each of the blends two films were compression molded, one at $130{ }^{\circ} \mathrm{C}$ and another one at $150{ }^{\circ} \mathrm{C}$. Pressed films were removed from the hot press and left to cool between two room temperature aluminum plates.

Table 1. Compositions of the blends of WG, PP, MWG and MPP.

\begin{tabular}{|c|c|c|c|c|c|}
\hline Type & Abbreviation & WG (wt.\%) & PP (wt.\%) & $\begin{array}{l}\text { MWG } \\
(w t . \%)\end{array}$ & MPP (wt.\%) \\
\hline \multirow{3}{*}{ Controls } & WG/PP 30/70 & 30 & 70 & - & - \\
\hline & WG/PP 50/50 & 50 & 50 & - & - \\
\hline & WG/PP 70/30 & 70 & 30 & - & - \\
\hline \multirow{3}{*}{$\begin{array}{l}\text { Only PP } \\
\text { Modified }\end{array}$} & WG/MPP 30/70 & 30 & - & - & 70 \\
\hline & WG/MPP 50/50 & 50 & - & - & 50 \\
\hline & WG/MPP 70/30 & 70 & - & - & 30 \\
\hline MWG/MPP & MWG/MPP 30/70 & - & - & 30 & 70 \\
\hline Modified in & MWG/MPP 50/50 & - & - & 50 & 50 \\
\hline Composite & MWG/MPP 70/30 & - & - & 70 & 30 \\
\hline
\end{tabular}

\subsection{SE-HPLC to Assess Protein Polymerization in Processed Composites}

The soluble amount of protein and protein size distribution of the protein powders, compression molded samples and composites were examined in this study. For this analysis, films were cut into approximately $0.2 \mathrm{~mm}$ pieces using a scalpel. Thereafter, $16.5 \mathrm{mg}( \pm 0.05 \mathrm{mg})$ of each sample was added to $1.4 \mathrm{~mL}$ buffer solution (0.5\% SDS, $0.05 \mathrm{M} \mathrm{NaH}_{2} \mathrm{PO}_{4}, \mathrm{pH}$ 6.9) in a Eppendorf tube (1.5 mL). To obtain the first extraction (1Ex) tubes were vortexed for $10 \mathrm{~s}$ (Whirli Vib 2, Labassco, Sweden) and then shaken for 5 min (IKA-VIBRAX VXR, IKA, Germany) at $2000 \mathrm{rpm}$. The tubes were then centrifuged (Legend Micro 17, Sorvall, Germany) for $30 \mathrm{~min}$ at 12,500 rpm and the supernatant was collected in HPLC vials. For the 2nd extraction (2Ex), extraction buffer $(1.4 \mathrm{~mL})$ was added to the pellet from 1Ex and then sonicated for $30 \mathrm{~s}$ at an amplitude of 5 microns using a Sanyo Soniprep 150 Ultrasonic Disintegrator (Tamro, UK) and thereafter centrifuged for $30 \mathrm{~min}$ and the supernatant collected in HPLC vials for analysis. The third extraction (3Ex) was similar to 2Ex, the pellet of 2Ex was used with sonication intervals of $30+60+60 \mathrm{~s}$, to avoid overheating, samples were left to cool at room temperature between each sonication interval. All three extractions (1Ex, 2Ex and 3Ex) were analyzed with a Waters 2690 Separation Module connected to a Waters 996 Photodiode Array Detector (Waters, Millford, MA, USA).

An SE-HPLC column (Biosep-SEC-S 4000, Phenomenex, Torrance, CA, USA) was used for protein size distribution determination. For each sample, $20 \mu \mathrm{L}$ was injected onto the column at an isocratic flow of $0.2 \mathrm{~mL} / \mathrm{min}$ ( $50 \%$ acetonitrile, $0.1 \%$ TFA; $50 \% \mathrm{H}_{2} \mathrm{O}, 0.1 \%$ TFA). Chromatograms were obtained 
at $210 \mathrm{~nm}$ and integrated using Empower Pro software (Waters, USA). The chromatograms were divided into two sections depending on the elution time of the proteins and total area was calculated. The high molecular weight $(\mathrm{HMw})$ proteins were eluted between 7-14.5 min and low molecular weight (LMw) between 14.5-28 min. HMw are referred to as polymeric proteins, and LMw as smaller molecular size proteins.

\subsection{Tensile Testing}

For mechanical testing the films were conditioned for at least $48 \mathrm{~h}$ at $23{ }^{\circ} \mathrm{C}$ and $50 \%$ relative humidity and then cut into dumbbell shaped samples (ISO 37 type 3, Elastocon, Sweden) and thereafter tested in the same conditions. Prior to testing the thickness of all the samples was measured at 5 different points (Mitutoyo IDC 112B) in the test area and the average was used for calculations. A clamp separation distance of $40 \mathrm{~mm}$, crosshead speed of $10 \mathrm{~mm} / \mathrm{min}$ and a $500 \mathrm{~N}$ load cell was used to test all samples on an Instron 5566 universal testing machine with a Bluehill software (Instron AB, Danderyd, Sweden).

\subsection{Fourier Transform Infrared Spectroscopy}

All the samples were dried for at least $72 \mathrm{~h}$ in a desiccator over silica gel prior to the analysis. FT-IR spectroscopy was carried out on all films and powders using a Spectrum 2000 FT-IR spectrometer (Perkin-Elmer inc., Norwalk, CN, USA) equipped with single reflection ATR (Golden Gate, Speac Ltd., USA). Data was Fourier self-de-convoluted using the Spectrum software with $\gamma=2$ and a smoothing factor of $70 \%$.

\section{Conclusions}

Chemical modification of plant proteins, through heating at a basic $\mathrm{pH}$, results in a protein with a decreased amount of intermolecular disulphide bonds and thereby a less cross-linked structure, as shown here for both WG and PP. Cross-linking of the proteins in the starting powder, when producing bio-based materials, largely impacts the properties of compression molded materials both in terms of opportunities for the proteins to further cross-link and form new bonds and structures during processing. From our previous study, mild protein extraction of WG has been shown to contribute with less cross-linked protein powder which when hot compression molded into films resulted in improved tensile properties (E-modulus and maximum stress) [5]. However, a less cross-linked structure in the protein starting material does not necessarily contribute to improved properties of processed bio-based materials. Here, a decrease in cross-linking of proteins by chemical modification, improved cross-linking (during temperature pressing) and tensile properties (E-modulus and maximum stress) of the material of PP but not for WG. Thus, using basic $\mathrm{pH}$ for modification of WG must contribute to irreversible changes in the protein conformation/structure and/or to chemical reactions not involving disulphide bond formation, which reduces the opportunities for the proteins to re-cross-link when processed. For PP, instead the chemical modification through basic $\mathrm{pH}$ contributed to the breaking of disulphide bonds which were created during industrial production of the PP starting material (the powder).

A major advantage with the chemical modification of PP was that it enabled the production of films with improved properties at a pressing temperature as low as $130^{\circ} \mathrm{C}$, thereby contributing to a lower environmental foot-print due to a reduction of energy use.

Thus, chemical modification of proteins for bio-based material production on an industrial scale may potentially help to widen the functional properties and improve the socio-economic value of the product (especially in the case of PP). Figure 6 provides a schematic summary of the important findings of this study. 

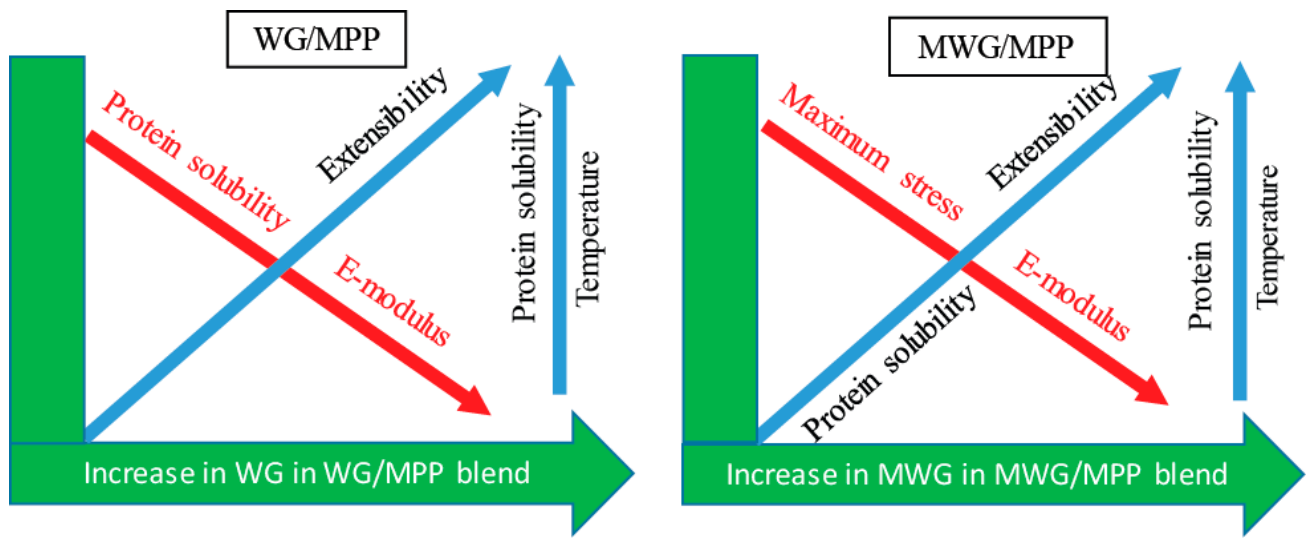

Figure 6. Schematic diagram of summarized effects of temperature and composition of the blend on protein polymerization and mechanical properties.

Supplementary Materials: Supplementary materials can be found at http:/ / www.mdpi.com/1422-0067/20/1/ 58/s1.

Author Contributions: R.K. conceived and designed the experiment together with F.M., F.M. performed the experiments and wrote the manuscript with contribution from the co-authors. M.S.H. performed FT-IR measurements and contributed with critical reading of the manuscript. R.K. contributed with performance of some SAXS analysis, coordinated SAXS experiments and obtained a beamtime for SAXS analysis, while T.S.P. contributed with interpretation of SAXS results. E.J. and R.K. contributed with obtaining of partial funding for this study and with critical commenting and writing of this manuscript.

Funding: This work was funded by the Swedish Governmental research program Trees and Crops for the Future (TC4F; Vinnova) and Partnerskap Alnarp.

Acknowledgments: We acknowledge Maria Luisa-Prieto Linde for her kind assistance in the laboratory, Lyckeby Starch AB for their kind provision of the potato protein and William Newson for his kind editing of the manuscript and English.

Conflicts of Interest: The authors declare no conflict of interest.

\section{Abbreviations}

$\begin{array}{ll}\text { Ex } & \text { Extraction } \\ \text { FT-IR } & \text { Fourier Transform Infrared Spectroscopy } \\ \text { HMw } & \text { High molecular weight proteins } \\ \text { LMw } & \text { Low molecular weight proteins } \\ \text { MPP } & \text { Modified potato protein } \\ \text { MWG } & \text { Modified wheat gluten } \\ \text { PP } & \text { Potato protein } \\ \text { SE-HPLC } & \text { Size Exclusion High Performance Liquid Chromatography } \\ T_{\mathrm{g}} & \text { Glass transition temperature } \\ \text { WG } & \text { Wheat gluten }\end{array}$

\section{References}

1. Kuktaite, R.; Newson, W.R.; Rasheed, F.; Plivelic, T.S.; Hedenqvist, M.S.; Gällstedt, M.; Johansson, E. Monitoring Nanostructure Dynamics and Polymerization in Glycerol Plasticized Wheat Gliadin and Glutenin Films: Relation to Mechanical Properties. ACS Sustain. Chem. Eng. 2016, 4, 2998-3007. [CrossRef]

2. Newson, W.R.; Rasheed, F.; Kuktaite, R.; Hedenqvist, M.S.; Gällstedt, M.; Plivelic, T.S.; Johansson, E. Commercial potato protein concentrate as a novel source for thermoformed bio-based plastic films with unusual polymerisation and tensile properties. RSC Adv. 2015, 5, 32217-32226. [CrossRef]

3. Neurath, H.; Greenstein, J.P.; Putnam, F.W.; Erickson, J.A. The chemistry of protein denaturation. Chem. Rev. 1944, 34, 157-265. [CrossRef] 
4. Du, Y.; Chen, F.; Zhang, Y.; Rempel, C.; Thompson, M.R.; Liu, Q. Potato protein isolate-based biopolymers. J. Appl. Polym. Sci. 2015, 132. [CrossRef]

5. Rasheed, F.; Hedenqvist, M.S.; Kuktaite, R.; Plivelic, T.S.; Gällstedt, M.; Johansson, E. Mild gluten separation-A non-destructive approach to fine tune structure and mechanical behavior of wheat gluten films. Ind. Crops Prod. 2015, 73, 90-98. [CrossRef]

6. Van Koningsveld, G.A.; Gruppen, H.; de Jongh, H.H.J.; Wijngaards, G.; van Boekel, M.A.J.S.; Walstra, P.; Voragen, A.G.J. Effects of $\mathrm{pH}$ and Heat Treatments on the Structure and Solubility of Potato Proteins in Different Preparations. J. Agric. Food Chem. 2001, 49, 4889-4897. [CrossRef] [PubMed]

7. Ullsten, N.H.; Cho, S.-W.; Spencer, G.; Gallstedt, M.; Johansson, E.; Hedenqvist, M.S. Properties of Extruded Vital Wheat Gluten Sheets with Sodium Hydroxide and Salicylic Acid. Biomacromolecules 2009, 10, 479-488. [CrossRef] [PubMed]

8. Pommet, M.; Morel, M.-H.; Redl, A.; Guilbert, S. Aggregation and degradation of plasticized wheat gluten during thermo-mechanical treatments, as monitored by rheological and biochemical changes. Polymer 2004, 45, 6853-6860. [CrossRef]

9. Olabarrieta, I.; Cho, S.W.; Gällstedt, M.; Sarasua, J.R.; Johansson, E.; Hedenqvist, M.S. Aging properties of films of plasticized vital wheat gluten cast from acidic and basic solutions. Biomacromolecules 2006, 7, 1657-1664. [CrossRef]

10. Ture, H.; Gallstedt, M.; Kuktaite, R.; Johansson, E.; Hedenqvist, M.S. Protein network structure and properties of wheat gluten extrudates using a novel solvent-free approach with urea as a combined denaturant and plasticiser. Soft Matter 2011, 7, 9416-9423. [CrossRef]

11. Rasheed, F.; Newson, W.R.; Plivelic, T.S.; Kuktaite, R.; Hedenqvist, M.S.; Gällstedt, M.; Johansson, E. Macromolecular changes and nano-structural arrangements in gliadin and glutenin films upon chemical modification: Relation to functionality. Int. J. Biol. Macromol. 2015, 79, 151-159. [CrossRef] [PubMed]

12. Kuktaite, R.; Plivelic, T.S.; Cerenius, Y.; Hedenqvist, M.S.; Gallstedt, M.; Marttila, S.; Ignell, R.; Popineau, Y.; Tranquet, O.; Shewry, P.R.; et al. Structure and Morphology of Wheat Gluten Films: From Polymeric Protein Aggregates toward Superstructure Arrangements. Biomacromolecules 2011, 12, 1438-1448. [CrossRef] [PubMed]

13. Ullsten, N.H.; Gällstedt, M.; Spencer, G.M.; Johansson, E.; Marttila, S.; Ignell, R.; Hedenqvist, M.S. Extruded High Quality Materials From Wheat Gluten. Polym. Renew. Resour. 2010, 1, 173-186. [CrossRef]

14. Gennadios, A.; Brandenburg, A.H.; Weller, C.L.; Testin, R.F. Effect of $\mathrm{pH}$ on properties of wheat gluten and soy protein isolate films. J. Agric. Food Chem. 1993, 41, 1835-1839. [CrossRef]

15. Kuktaite, R.; Türe, H.; Hedenqvist, M.S.; Gällstedt, M.; Plivelic, T.S. Gluten Biopolymer and Nanoclay-Derived Structures in Wheat Gluten-Urea-Clay Composites: Relation to Barrier and Mechanical Properties. ACS Sustain. Chem. Eng. 2014, 2, 1439-1445. [CrossRef]

16. Newson, W.R.; Kuktaite, R.; Hedenqvist, M.S.; Gällstedt, M.; Johansson, E. Effect of Additives on the Tensile Performance and Protein Solubility of Industrial Oilseed Residual Based Plastics. J. Agric. Food Chem. 2014, 62, 6707-6715. [CrossRef]

17. Kowalczyk, D.; Baraniak, B. Effects of plasticizers, $\mathrm{pH}$ and heating of film-forming solution on the properties of pea protein isolate films. J. Food Eng. 2011, 105, 295-305. [CrossRef]

18. Domenek, S.; Morel, M.-H.; Bonicel, J.; Guilbert, S. Polymerization kinetics of wheat gluten upon thermosetting. A mechanistic model. J. Agric. Food Chem. 2002, 50, 5947-5954. [CrossRef]

19. Gällstedt, M.; Mattozzi, A.; Johansson, E.; Hedenqvist, M.S. Transport and Tensile Properties of Compression-Molded Wheat Gluten Films. Biomacromolecules 2004, 5, 2020-2028. [CrossRef]

20. Muneer, F.; Johansson, E.; Hedenqvist, M.S.; Plivelic, T.S.; Markedal, K.E.; Petersen, I.L.; Sørensen, J.C.; Kuktaite, R. The impact of newly produced protein and dietary fiber rich fractions of yellow pea (Pisum sativum L.) on the structure and mechanical properties of pasta-like sheets. Food Res. Int. 2018, 106, 607-618. [CrossRef]

21. Gontard, N.; Guilbert, S.; Cuq, J.-L. Water and Glycerol as Plasticizers Affect Mechanical and Water Vapor Barrier Properties of an Edible Wheat Gluten Film. J. Food Sci. 1993, 58, 206-211. [CrossRef]

22. Johansson, E.; Malik, A.H.; Hussain, A.; Rasheed, F.; Newson, W.R.; Plivelic, T.; Hedenqvist, M.S.; Gällstedt, M.; Kuktaite, R. Wheat Gluten Polymer Structures: The Impact of Genotype, Environment, and Processing on Their Functionality in Various Applications. Cereal Chem. J. 2013, 90, 367-376. [CrossRef] 
23. Newson, W.R.; Kuktaite, R.; Hedenqvist, M.; Gällstedt, M.; Johansson, E. Oilseed Meal Based Plastics from Plasticized, Hot Pressed Crambe abyssinica and Brassica carinata Residuals. J. Am. Oil Chem. Soc. 2013, 90, 1229-1237. [CrossRef]

24. Gerrard, J.A. Protein-protein crosslinking in food: Methods, consequences, applications. Trends Food Sci. Technol. 2002, 13, 391-399. [CrossRef]

25. Lagrain, B.; Goderis, B.; Brijs, K.; Delcour, J.A. Molecular basis of processing wheat gluten toward biobased materials. Biomacromolecules 2010, 11, 533-541. [CrossRef] [PubMed]

26. Rombouts, I.; Lagrain, B.; Delcour, J.A.; Türe, H.; Hedenqvist, M.S.; Johansson, E.; Kuktaite, R. Crosslinks in wheat gluten films with hexagonal close-packed protein structures. Ind. Crops Prod. 2013, 51, 229-235. [CrossRef]

27. Giosafatto, C.; Al-Asmar, A.; D’Angelo, A.; Roviello, V.; Esposito, M.; Mariniello, L. Preparation and Characterization of Bioplastics from Grass Pea Flour Cast in the Presence of Microbial Transglutaminase. Coatings 2018, 8, 435. [CrossRef]

28. Ceresino, E.B.; de Melo, R.R.; Kuktaite, R.; Hedenqvist, M.S.; Zucchi, T.D.; Johansson, E.; Sato, H.H. Transglutaminase from newly isolated Streptomyces sp. CBMAI 1617: Production optimization, characterization and evaluation in wheat protein and dough systems. Food Chem. 2018, 241, 403-410. [CrossRef]

29. Ceresino, E.B.; Kuktaite, R.; Sato, H.H.; Hedenqvist, M.S.; Johansson, E. Impact of gluten separation process and transglutaminase source on gluten based dough properties. Food Hydrocolloid. 2019, 87, 661-669. [CrossRef]

30. Morel, M.H.; Redl, A.; Guilbert, S. Mechanism of heat and shear mediated aggregation of wheat gluten protein upon mixing. Biomacromolecules 2002, 3, 488-497. [CrossRef]

31. Rasheed, F.; Newson, W.R.; Plivelic, T.S.; Kuktaite, R.; Hedenqvist, M.S.; Gallstedt, M.; Johansson, E. Structural architecture and solubility of native and modified gliadin and glutenin proteins: Non-crystalline molecular and atomic organization. RSC Adv. 2014, 4, 2051-2060. [CrossRef]

32. Blomfeldt, T.O.J.; Kuktaite, R.; Johansson, E.; Hedenqvist, M.S. Mechanical Properties and Network Structure of Wheat Gluten Foams. Biomacromolecules 2011, 12, 1707-1715. [CrossRef] [PubMed]

33. Muneer, F.; Andersson, M.; Koch, K.; Menzel, C.; Hedenqvist, M.S.; Gallstedt, M.; Plivelic, T.S.; Kuktaite, R. Nanostructural Morphology of Plasticized Wheat Gluten and Modified Potato Starch Composites: Relationship to Mechanical and Barrier Properties. Biomacromolecules 2015, 16, 695-705. [CrossRef] [PubMed]

34. Nowick, J.S. Exploring $\beta$-sheet structure and interactions with chemical model systems. Acc. Chem. Res. 2008, 41, 1319-1330. [CrossRef] [PubMed]

35. Jackson, M.; Mantsch, H.H. The Use and Misuse of FTIR Spectroscopy in the Determination of Protein Structure. Critical Rev. Biochem. Mol. Biol. 1995, 30, 95-120. [CrossRef] [PubMed]

36. Cho, S.W.; Gällstedt, M.; Johansson, E.; Hedenqvist, M.S. Injection-molded nanocomposites and materials based on wheat gluten. Int. J. Biol. Macromol. 2011, 48, 146-152. [CrossRef] [PubMed]

37. Blomfeldt, T.O.; Kuktaite, R.; Plivelic, T.S.; Rasheed, F.; Johansson, E.; Hedenqvist, M.S. Novel freeze-dried foams from glutenin-and gliadin-rich fractions. RSC Adv. 2012, 2, 6617-6627. [CrossRef]

38. Muneer, F.; Andersson, M.; Koch, K.; Hedenqvist, M.S.; Gällstedt, M.; Plivelic, T.S.; Menzel, C.; Rhazi, L.; Kuktaite, R. Innovative Gliadin/Glutenin and Modified Potato Starch Green Composites: Chemistry, Structure, and Functionality Induced by Processing. ACS Sustain. Chem. Eng. 2016, 4, 6332-6343. [CrossRef]

39. Sun, S.; Song, Y.; Zheng, Q. Thermo-molded wheat gluten plastics plasticized with glycerol: Effect of molding temperature. Food Hydrocolloid. 2008, 22, 1006-1013. [CrossRef]

40. Muneer, F.; Johansson, E.; Hedenqvist, M.S.; Gällstedt, M.; Newson, W.R. Preparation, Properties, Protein Cross-Linking and Biodegradability of Plasticizer-Solvent Free Hemp Fibre Reinforced Wheat Gluten, Glutenin, and Gliadin Composites. BioResources 2014, 9, 5246-5261. [CrossRef]

(C) 2018 by the authors. Licensee MDPI, Basel, Switzerland. This article is an open access article distributed under the terms and conditions of the Creative Commons Attribution (CC BY) license (http:/ / creativecommons.org/licenses/by/4.0/). 